\title{
THE CONTRIBUTION OF LABOUR TO THE DEMOCRATIZATION PROCESS IN NIGERIA
}

\author{
Nuhu Yaqub
}

Being paper presented at the IPSA Study Group on Democratization: Regional Conference on "Problems of Democratization in Africa" held at the Centre for Democratic Studies, Bwari, Abuja, Nigeria, from September 20-24,1992; revised for publication in January 1994.

\section{INTRODUCTION}

The paper takes off with certain assumptions which are germane and are therefore meant to guide analysis. In the first place, it is assumed that Nigeria, as a capitalist social formation, has not been a democratic society and, like many other countries at similar or somehow different levels of technological and social development along the capitalist route, aspires to become democratic. (As will be shown below, the pattern of colonial intervention in Nigeria's development has had a long lasting effect on this absence of democracy.) Secondly, it is assumed that in historical terms and taken holistically, the bourgeois mode, i.e., capitalism, has extended the frontiers of democracy much more than any other previous modes. But because bourgeois democracy is a class democracy, it has compromised and denied democracy's ideals which include equality, freedom, justice, popular participation, etc., to the majority of the population - the working class - under its hegemony. As a result of this partial or non-fulfillment of democracy's ideals, labour, and this is the third assumption the paper would make, is charged, especially from the Marxist perspective, with the responsibility of advancing further the process of democratization that inevitably became extensive and intensive from the hegemonization of capital in the bourgeois society. In other words, labour is expected to wage political struggles to win democracy for its class and the other down-trodden classes. In victory, however, labour's democracy would still be a class democracy; but it is much more than that, as labour is expected to use state power it might capture to advance and deepen democracy farther through principally the abolitions of private property and the state. It is only through this process that labour can be part of the "democratization process", anything less than this, the paper finally assumes, will consign labour's role to merely expressing and demonstrating "trade union consciousness". 
On the basis of these assumptions this paper will attempt to document the role labour has played in the process of democratization in Nigeria. In particular, we would be concerned with how labour has tried to be involved with the political development of the country and what has been the outcome. Also it $\mathrm{k}$ intended to underscore the forces or factors that would have militated against a successful deepening of the democratization process in the country.

The paper is structured as follows: we shall start conceptually by analyzing what we mean by labour and the labour process; historically, though briefly, the paper will discuss the development of capitalism and how, at the imperialist stage, it metamorphosed into colonialism. The analysis of the negative impact of colonialism on democratization hi Nigeria will then be given; this is co-joined by an analysis of decolonization and the role played by labour. The period of independence to the political debacle of 1993 will be analyzed, to underscore the general result of the democratization process in the country, and the obstacles posed to the labour movement by the corporatist designs of the Nigerian state.

\section{LABOUR AND THE LABOUR PROCESS}

Labour, conceptually speaking, "is... an interaction between the person who works and the natural world such that elements of the latter are consciously altered in a purposive manner". In a labour process, three important elements are involved: "first, the work itself, a purposive productive activity, second, the object(s) on which that work is performed; and third, the instruments which facilitate the process of work". From this definition, it can be said that the labour process lies at the basis of human existence; this is in the context that for man (used in the generic sense to include woman) to exist, to survive, etc., he needs to be involved in a conscious activity, aimed at changing nature (to meet or satisfy his needs). The labour process can actually be called the pre-condition for man's survival as invariably the resources to be turned into usable assets "do not (always) exist in the form that is directly beneficial to man".

Also from the above definition, the labour process except in extremely primitive societies of antiquity is more often than not a collective and/or a co-operative undertaking. It is not, in other words, a process anyone can solely begin and complete without the contribution of others. This is because apart from the 'raw materials' that nature may provide some of the tools through which labour works on its objects are "always the result of previous labour processes, and their character is related both to the degree of development of labour and to the social relations under which the work is performed". With division of labour in the wake of the ever increasing complexity of the labour process, this cooperativeness has further been made tine qua non.

But the emergence of private property, classes and, in particular, the development of capitalism not only affected this co-operation principle both in theory and in practice, but, fundamentally speaking, the means of production and labour power have since become commodities purchasable in the market place by the capitalist. The labour process is thus transformed to 
meet exchange values:

The capitalist... 'consumes' labour power by causing the bearers of labour power (workers) to consume means of production by their labour. Work is thereby performed under the supervision, direction and control of the capitalist, and the products produced are the property of the immediate producers...

These products are use values for the capitalist only in so far as they are bearers of exchange value. The purpose of the capitalist labour process is to produce commodities whose value exceeds the sum of labour power and means of production consumed in the process of production. Thus, this production process is both a labour process creating use values, and a valorization process creating values the latter only being possible because of the difference between the exchange value and the use value of labour power. (Emphasis in the original).

THE DEVELOPMENT OF CAPITALISM AND THE SERIES OF STRUGGLES OF THE WORKING CLASS FOR IMPROVED EXISTENTIAL CONDITIONS AND DEMOCRACY

The development of capitalism has historically followed the pattern whereby there existed or shall exist (i.e. in countries that are yet to be fully capitalist) a class of individuals that were or are 'free' to sell their labour power. There must be however in the market (or exchange bureau) another class-grouping - the capitalists - who would be able, willing, and ready to buy the labour power on offer or on sale. Theoretically, the two classes are 'equal' in this process of buying and selling; but given the exploitative nature of the capitalist system such equality is a sham or a mere formality. For instance, the emergence of the working class resulted from the destruction of the feudal mode which, though encumbered the serfs with a number of debilities, nonetheless ensured that the serfs maintained their ownership of the means of production - land. But the destruction of feudalism and the consequent expulsion of the serfs/peasantry from the land in the wake of both the agrarian and industrial revolutions left the emergent working class with only one option: to sell its labour power under the yoke of wage slavery or, due to hunger and other wants, perish in the urban centres to which members of the class increasingly flocked. ${ }^{6}$

This situation could not, therefore, have created any equality in the relationship between the two classes. It is obvious that the class with the wherewithal to buy the other's labour power could accumulate and exercise a preponderant power over the one that was under compulsion to sell. Under such a social order, democracy could not thrive; at best, the ideal of equality that democracy is assumed to champion would only be that between the 
members of the owning class; and even within this same class, it would be differentially accessed, accumulated, or expressed - given the different levels of extracted surplus.

The unequal relationship between the working class and the bourgeoisie would not be exhausted in the market place of buying and selling. A hired worker (or one whose labour power had been purchased) would have to submit to other conditions in the work place. His new master would define how long he would work so that the capitalist's primary objective of profit maximization could be realized. This means he would, as indicated above, have to produce surplus values. As a result of the exploitative tendency inherent in capitalism, democracy's other concept of justice (i.e. fair treatment, the granting of what is due, etc.) is not practicalized, or is, to sound quite optimistic, not realized. Indeed, its realization would occasion capitalist transcendence.

In the late 18th and early part of the 19th centuries - the period which coincided with the dramatic changes wrought by capitalism in Europe - the conditions of the working class were indeed very bad. Workers were made to work long hours, under squalid sanitary conditions; and children (in some cases less than ten years) and women were also subjected to dehumanizing conditions of work.

In addition, because of the inherent crisis of capitalism - its cycles of boom and bust - workers often found themselves in the job market, searching for employment after retrenchment. And because of the existence of the "industrial reserve army", there would be competition (among the workers) for the few available jobs. This phenomenon often resulted in the depression of the, wages for workers in general. On the other hand, the capitalist class seldom got adversely affected up to the same extent by this decline in income.

What is more, at the superstructural level, the working class in the beginning hardly mattered in the politics of its country. Since in the final analysis it is the base (structure) which determines the superstructure, and since the economy - in terms of ownership, control and/or management - was inaccessible to the working class, the politics of the early bourgeois society was equally and effectively denied to this category of people. Consequently, it would not only be true that the bourgeoisie would have the means to partake in politics, but the laws enacted largely took care of the moral, legal as well as the ideological basis of the capitalist social order. Working class erosion of the absolute hegemony of the bourgeoisie, as a matter of historical development, began as a gradual process, and this was only through a series of struggles.

The vehicle through which this process took shape has been the trade union movement. The initial impetus for the formation of the trade union was the need to use it for the improvement in the lot of the workers. According to Engels:

What gives these Unions and the strikes arising from them their real importance is this, that they are the first attempt of the workers to abolish competition. They imply the recognition of the fact that the supremacy of 
the bourgeoisie is based wholly upon the competition of the workers among themselves; i.e. upon their want of cohesion. And precisely because the Unions direct themselves against the vital nerve of the present social order, however onesidedly, in however narrow a way, are they so dangerous to this social order. The working-men cannot attack the bourgeoisie, and with it the whole existing order of society, at any sorer point than this. If the competition of the workers among themselves is destroyed, if all determine not to be further exploited by the bourgeoisie, the rule of property is at an end.

What might have given the working class this ability to organize and strike has been the characteristic social nature of production and the workers' large concentration in the work place which the capitalist system has occasioned.

Beyond the need to use the trade union to demand for better conditions of service, there was, as stated above, the anticipation that the workers would not only use this vehicle to advance the cause of democracy, but also use it to advance the cause of the revolutionary transformation of the bourgeois social order. Actually, both Marx and Engels, in their various early writings, anticipated that the participation of the workers in the struggles, whether economic or political, particularly the latter, would lead to the attainment of this result. Although the revolutionary transformation of the bourgeois societies of their time did not materialize nor have they largely since, the development of trade unionism has historically been salutary. For instance, the working class won the battle for an 8-hour working day; 40-hour working week; improvement in the sanitation of the work place; an end to child labour; paid leave; maternity leave for the working mothers; an end to discrimination through the institution of the principle and policy of equal pay for equal work; the establishment of the welfare state, etc.

Perhaps the greatest achievement from the struggles of the working .class has been the extension of the franchise to the groups that initially were excluded from the political process in bourgeois society. The groups that thus benefitted have included the women, migrant groups and other minorities. In addition, the principle of universal adult suffrage in which age and sanity are used as principles to determine those who could partake in the political process, is firmly entrenched in contemporary advanced bourgeois societies. The extension of the franchise and the acceptance of the principle of universal adult suffrage have remained the corner-stones of the liberal democratic (bourgeois) representative order; and both politicians and academicians that operate within this perspective are wont to accept this reality of the bourgeois system as the pinnacle of democracy, even if its weaknesses are also admitted.

As a result of the dominance and hegemony of liberalism we can briefly summarize this section by saying (i) that in bourgeois society, the class nature of democracy has not been transcended; and (ii) which is obvious, that labour is still relatively marginalized in the crucial aspect of the democratization of 
bourgeois society - even though its struggles have contributed to the deepening and the advancement of this variety of democracy. ${ }^{12}$

\section{THE IMPOSITION OF COLONIALISM AND THE DEVELOPMENT OFTHE WORKING CLASS IN NIGERIA}

Colonialism is essentially about the domination of an alien power over a subjugated people. It is also a process whereby the values - ideological and material - of the dominant power are transplanted into the colonized territory. Nigeria, like a number of countries in Africa, was colonized by Britain.

The contact between Britain and what eventually became Nigeria spanned several centuries. Initially at least, most European nations in contact with African peoples restricted themselves to trading and trade links. The events in Europe - the break-down of the feudal system and the increasing tempo of capitalist industrialization - led to a decisive and more dramatic relationship between Europe and Africa. In the case of Nigeria, this change witnessed also a transition from laissez faire trade links to the eventual imposition of British colonialism. (In parenthesis, it must be admitted that British machination to possess the Nigerian territory did not only get challenged from fellow European powers, but also from the erstwhile African 'middlemen' (that blossomed during the slave trade era) who did not wish to be jettisoned. As a result of the challenges from fellow Europeans, Britain and the other European powers engaged in the 'scramble' for Africa repaired to Berlin between November 1884 to January 1885, to parcel out Africa amongst themselves. Africans were scarcely or in any token manner represented in the whole exercise that has remained a historic event shaping their destiny. This is the first point where the inherent participatory aspect of democracy was dispensed with and the future of democracy in Africa, both during and after colonialism, has been argued elsewhere to be fragile.

British suzerainty - meaning its effective exercise of power and control over Nigeria could be roughly estimated to have lasted between 1861 (when Lagos was ceded as a colony) and 1960 (when nominal independence was attained). Despite differential periods of occupation, the British attempted to apply a uniform colonial policy over the country, this was especially so after the amalgamation of the Northern and Southern Protectorates in 1914. Thus, the principal administrative policy of 'indirect rule', tested and found to be effective in the northern emirate system, was extended to the southern parts of Nigeria. The indirect rule system met with some stiff opposition from the eastern part (of the country), particularly among the Ibos that never really until colonial intervention came under a central and overarching authority. The "Aba Women's Riot" of 1929 was thus a direct consequence of the colonialists' limited understanding of the sociological differences of the Nigerian peoples.

Other instruments of entrenching British colonialism included the introduction of poll tax, tributes and other levies, the development of infrastructural facilities such as roads, the railways and the ports. These faculties were to enhance- the British primary motive of embarking on 


\section{Annals of the Social Science Council of Nigeria, No.5, 1993}

colonialism: the exploitation of the mineral, human and agricultural resources of Nigeria. Also the development of these facilities and the implementation of certain imperial policies were aimed at ensuring that Nigeria would become a site for capitalist investment, to help bolster capitalism back in the metropole.

Perhaps, on the basis of the concern and focus of this paper, the greatest impact of colonial imposition was expressed in the development of the working class. Starting initially with the pre-occupation to produce cash crops to feed the metropolitan industries the peasantry was created by colonialism in Nigeria. As there was also the need that the peasants' produce should get to the market or get evacuated from the points of production, the construction of infrastructural facilities was equally embarked upon, with a uniqueness that only the logic of colonialism could explain. For instance, roads and rail lines would only be constructed in or extended to areas where cash crop production and the exploitation of minerals would make these facilities viable.

The colonial authorities required labour for the rail roads, motor roads as well as the harbours to be thus constructed. As pay was very poor and realizing that this could discourage Nigerians from going into wage employment, the colonialists introduced also levies and other legislations to get some of the required labour. Some of the legislations that were directed to this end included: the Proclamation No. 15 of 1903 which compelled all abled-bodied men and women to work with or without pay, in accordance with the directives of the warrant chiefs and other traditional authorities $;{ }^{16}$ the Northern Nigeria Road Proclamation also of 1903 which aimed to legalize compulsory labour in that part of the country, the Masters and Servants Ordinance of 1917 which aimed to govern the "conditions and recruitment of labour, method of payment, use or native carriers, etc."; ${ }^{18}$ the Forced Labour Ordinance of 1929 which not only up-dated the Masters and Servants Ordinance but also gave indication of some categories of unskilled labour whose wages would not exceed four shillings per day; ${ }^{19}$ and the Forced Labour Ordinance of 1933 which radically amended the previous one of 1929 with respect to the prohibition of the practice of certain forms of forced labour. ${ }^{2 "}$

Either as a result of these measures or because of the increasing integration of the Nigerian economy into the capitalist nexus, the size of the working class gradually grew. For instance, of the 236,000 wage earners estimated by 1946, 135,000 comprised government and native authority employees while 101,000 were non-government workers. The latter category was further sub-divided into 68,000 employed by colonial firms, 16,000 in Christian missions, 15,000 in African enterprises, and 2,000 in Levantine establishments. By 1960, the estimate put those in government and nongovernment employments at 184,225 and 238,650 respectively. ${ }^{22}$

The growth in the work-force also led the colonial state to introduce legislations to guide industrial relations practice. Among the principal ones between 1930 and 1960 were: the Trade Union Ordinance of 1938 that legalized trade unionism for five or more workers in an establishment; and the Workmen's Compensation Act No.51 of 1941 that specified compensation 
for industrial injuries or accidents. The Act was later amended by the 1950 Workmen's Compensation (Amendment Ordinance No. 23) and the 1957 Workmen Compensation (Amendment Ordinance No. 25). There were also the Trades Disputes Arbitration and Inquiry Ordinance No. 3 of 1941 (as its name implies it was meant to settle trade disputes); the Factories Ordinance of 1955 which was meant to ensure safety at work place as well as to authorize factory inspectors to carry out routine checks on safety, and the National Provident Fund Act No. 20 of 1957 which was meant to secure income for the workers during old age and/or sickness. ${ }^{23}$

The colonial system was itself a bundle of contradictions. Its exploitation of Nigeria's mineral and agricultural resources could hardly have been tolerated - of course, by the colonized people of Nigeria. Furthermore, $\mathrm{k}$ became dear that the exploitation of the country's resources were not invested within the economy to expand and modernize the productive forces; rather such exploitation largely served the interests of Britain - thus giving rise to the phenomenon that radical sociologists and political economists have referred to as the "development of underdevelopment" or simply the dependency syndrome. ${ }^{24}$

At another level a contradiction manifested itself antagonistically in the relations with the social forces that colonialism spawned. From the account given above on the development of the working class it is clear that the primary contradiction would be between the colonial state and this class; indeed many skirmishes took place between them (see next section). On the other hand, there was the petty-bourgeoisie - the strata comprising the upper echelon of the colonial bureaucracy, the western educated professionals such as lawyers, doctors, engineers, journalists, etc. - who discovered that they severally and/or collectively suffered one form of discrimination or another from the iniquitous colonial system. Particularly under the leadership of the petty-bourgeoisie, oppositions to colonial imposition coalesced into a historic struggle for democratization (which was also a contradiction because of its denial or new-existence) in the Nigerian social formation.

In the next section, we shall examine the decolonization cum democratization process with particular attention paid to the role played by the working class.

\section{DECOLONIZATION, DEMOCRATIZATION AND LABOUR}

Although a distinction could theoretically and practically be made between a radical politics of decolonization and the non-radical type, in this paper decolonization is genetically understood to be the mobilization of a colonized people for self-determination, participation and an end to the colonial system of exploitation and domination. In this sense, the decolonization process anywhere has a democratic strand; it is only the nature of the class that assumes power at the terminal point of colonialism that determines whether or not the essentials of democracy are attained and entrenched. This point makes $\mathrm{k}$ pertinent to understand the role that labour or the working class plays in such decolonization process as $\mathrm{k}$ is considered to be the class with the historical mission to institute democracy. 
Even before the 1938 Act legalizing trade unionism, many trade unions had existed in Nigeria, and they had carried out purely trade union activities. ${ }^{27}$ The circumstance leading to trade union activism could hardly be separated from the difficulties occasioned first by the depression of 1929-1939, and the scarcities that arose in the wake of the exigencies of the second ultra-imperialist war of 1939-1945, in the second place. In the third place, the responses of the colonial administrators to workers' demands clearly indicated that they were either incompetent in handling such workers' grievances or that they simply wanted to play mischief - by openly espousing and preaching racism and unnecessary discrimination. ${ }^{28}$ It was particularly this latter aspect that combined with the misgivings which mainstream nationalists had against colonialists, to produce anticolonial sentiments, increased strikes, and other concerted actions. For instance, nationalists such as the late Chief Obafemi Awolowo was noted to be active in trade union issues as far back as $1937 ;{ }^{29}$ while Azikiwe's

brands of combative nationalist agitation and aggressive journalism... focused public attention on the various forms of colonial exploitation (including the exploitation of Nigerian labour) and inspired confidence among many Nigerians in their ability to end colonial rule through the intensification of activist political and working class agitations. ${ }^{30}$

Similarly, the emergence in the early thirties of Chief Michael Imoudu on the labour movement scene was to serve as a catalyst to its radicalism in the $30 \mathrm{~s}, 40 \mathrm{~s}, 50 \mathrm{~s}$, 60 s, until his premature retirement from trade union activities by the military fascists in 1977. (This point is, however, not to underrate the heroic role of other trade unionists in the early years of the struggle to improve the lot of the workers and to also contribute to the political emancipation of the country). Statistically speaking, the result of this radicalism of the trade union movement led to the number of disputes and strikes rising:

sharply to 16 and 10 respectively in 1946; 70 and 36 in 1949 when 46,698 workers were involved, causing a loss of 500,000 working days. The peak (under colonialism) was in 1959-1960 with 115 disputes and 54 stoppages, involving about 23,250 workers and some 70,862 working days. ${ }^{32}$

Among these struggles, the most celebrated, the most successful, and the most effective in impact was the General Strikes of 1945 which:

in Lagos... lasted for 44 days, but in the provinces (now Regions)... dragged on for as long as 52 days. Estimates of the total number of workers involved... vary. Coleman puts it at 30,000; Padmore quotes the figure as 150,000. 
Labour Department figures appear to be more reliable (sic). According to its Annual Report for 1945, the total number of workers involved was 42,951. Of this figure 41,165 were public employees, who were directly involved; the rest were employees of commercial and construction companies, who came out in sympathy. ${ }^{33}$

In short, it led the colonial state to set up the Tudor Davies Commission whose report, among others, upheld the grudges of the workers against high cost of living; awarded increase in the cost of living allowance (COLA) and made other recommendations.

Finally, in the circumstances of increased tempo of trade unionism, the number of registered unions steadily rose from 14 in 1940 to 347 in 1959/60; with membership also rising from 4,629 in 1940 to 259,072 in 1959/60. ${ }^{35}$

The perspective of this paper is that when workers' struggle transcends the purely trade union demands to raise issues about the nature of the state, its class configurations and how the working class could capture power, etc., the democratic agenda is being addressed. These workers' struggles, there is no doubt, recorded some successes as the colonial state either conceded wage increases, granted improvement in their other financial and non-financial conditions of services, re-organized the labour processes, etc. Nonetheless the democratic project was aborted. Why was this?

In the first place, the bulk of the leadership of the working class and possibly the rank and file never developed beyond what Lenin and other revolutionaries referred to as 'trade union consciousness'. This factor seriously underscored the inevitable failure in the various attempts to form a central labour union. In other words, there was an ideological divide, quite early, in Nigeria's labour movement. There were those, led by Imoudu, who wanted to link the economic with the political and saw a powerful labour front as a vehicle to advance the struggle towards socialism. ${ }^{37}$ For others, that is, the right-wing labour leaders, while individual workers could be politically active, the trade union movement should be apolitical and neutral -forgetting in their naivete that the bourgeois colonial state was not any of these.

There were also different approaches by these two groups to the issue of affiliation with international labour organizations (the world Federation of Trade Unions and the International Confederation of Free Trade Unions, respectively) representing the EastWest global rivalry. ${ }^{38}$ This split in the trade union movement, which even went beyond the colonial period to 1977 when the military government forced unity, is to be one major factor in the non-development of the democratic process in Nigeria. There was also the point about the poor leadership provided by the leaders of the trade unions. Some of the leaders were corrupt, inefficient, and knew next to nothing about trade unionism.

The second major factor was external to the trade union movement. The colonial state was anxious to see a pliable labour movement; and where this was not possible, to enact legislations that would rein it in. In pursuit of this objective, more often than not, dedicated trade union leaders were 
harassed, intimidated and incarcerated. (Imoudu's was a typical example of this kind of treatment.) Employers of labour, knowing that the colonial state would give support, also tried to emasculate the possible development in democratic culture which could lead to the rise of the ideological consciousness of the workers if they embraced socialism. They largely achieved this objective through dismissing workers and meting out other punitive measures. Thus, in general, the Nigerian working class was oriented into fighting heroic battles to improve its existential conditions which, as already indicated, met with some success.

Perhaps, the limited or lack of success of the working class to advance democracy in Nigeria should not be divorced from the nature of the state and society the British wanted to develop. Despite its weak democratic foundation or contrary to its democratic pretensions, in Nigeria as in other colonies, the British wanted a society and a state in which private capital would be hegemonic. The colonies, obviously, were not capitalist; but the colonizing state readily provided a model. In the British model, therefore, the trade union could affiliate with the labour party, but it would not on its own contest elections nor sponsor candidates contesting elections on organs other than those of political parties. And since Nigeria was to be a site where private capital could be invested profitably, trade unions were not to raise issues beyond their primary trade union concerns.

This was what largely happened in Nigeria even if at the General Council meeting of the Trade Union Congress of Nigeria (TUC) on November 29,1947, it was resolved that the TUC should continue to affiliate with the National Council of Nigeria and the Cameroon (NCNC) until the formation of its proposed labour party. A Labour Party was never formed before colonialism came to an end. Even if it was formed, there was no indication that (i) it would be a proletarian party, in the vanguard for the emancipation of the workers and the other classes; (ii) the various workers' unions collectively or workers as individual would join and become members; and (iii) the colonial state would allow it to operate successfully.

In addition, in the aftermath of the intra-imperialist war and up to independence in 1960, the nationalists, realizing that they had no foothold in accumulation, also resisted a vanguard role the working class in the democratization process. This constituted the other sector where workers would have met with opposition. That is, assuming that all workers would have been members of the proposed labour party, the nationalists would have faced stiff opposition in terms of where and how to mobilize people against colonialism. Their integrity as the spokespeople of Nigerians would have therefore been destroyed.

On the other hand, as the nationalist generally desired a foothold in accumulation, sharing power with the working class in a manner that would enhance the democratization process was considered by them to be self-defeating; something that needed to be avoided by all means. Thus, the British model of collective bargaining with its emphasis on apolitical trade unionism which served the nationalists' purpose pretty well was promoted, even after independence. In the next and final (main) section, we shall consider further this abortion of the democratization process with its consequence for the Nigerian polity and the labour union. 


\section{INDEPENDENCE, DEMOCRATIC FAILURE AND LABOUR}

Independence, meaning political independence, was achieved with fanfare on October 1st, 1960. Both the British who superintended the transition and the nationalists who opportunistically were thrust into power never fully questioned the essence of this independence. For the British in particular, it was alright and its 'mission of civilization' was complete in so far as the independence handed to the nationalists allowed private foreign capital to thrive. It mattered less if the people remained poverty-stricken, struck by disease, infested with ignorance and viciously exploited. In a situation of this nature, it could hardly be said that a nation was born nor could it be said for sure that democracy would be nourished.

As for the Nigerian leaders, they were generally too uneducated to understand or appreciate the dynamics of a modern polity, the nature of imperialism, and the consequence of its exploitation. Hence, they assumed that a colonial structure could be inherited without any fundamental restructuring to govern a post-colonial society. For instance, too much fetishness was made of the formalistic structures such as multi-party system, the Westminster model, federalism, etc., without being bothered about the underlying economic foundations, the national question, particularly the issue of national integration, and the mechanics of addressing the problems of society. The crisis of accumulation that was engendered by the leadership's lack of a strong basis in production and distribution - i.e, the lack of a middle class - meant that its politics would continue the heritage from colonialism - the assault on democracy. Consequently electoral fraud would be committed with impunity; opponents would be beaten, maimed, or killed, etc. all in an effort to perpetuate in power the cabal to whom independence was handed. The result is that this kind of politics was terminated in 1966 by a group of army officers.

Meanwhile, the trade union movement continued on its 'disunity" course. Again petty jealousy, crass opportunism and, to a certain extent, ideological differences continued to bedevil unity and the formation of a central labour front. Efforts were made by both the union leaders and the government of Tafawa Balewa to forge unity; but such efforts usually ended soon after they were initiated and launched.

Unity was, however, objectively forced on the feuding unionists in a prelude to the general strike of 1964. (This is referring to the setting up from 1963-1965 of a Joint Action Committee (JAC) of Nigerian Trade Unions.) Apart from the unedifying bourgeois politics which the working classes and the other exploited classes were constantly subjected to, the background of the strike was:

...the mounting cost of living (which) had sucked away a third of the earning power of the few pennies that workers were being paid... the wage freeze policy of the Balewa regime... to attract foreign firms and financiers 
by enabling them to earn high profits... The plight of daily paid workers was unbearable. There were scandalous wage discriminations throughout the country. But the workers raised their weary eyes and saw the Balewa sharks, foreign and local, feeding fat and growing by leaps and bounds. Parliamentarians and Ministers of State, for instance, raised their salaries to the skies by simple agreement. ${ }^{41}$

Thus, the strike, actually staged on September 27, 1963, forced government to appoint the Morgan Commission. There was delay in releasing its report (having completed the assignment in April 1964). This triggered off the second general strike in the history of the country. This strike was also considered to be highly successful and it did result in substantial concessions to the workers.

Soon after this momentous event there were the military coups d'etat of 1966 in January and July and the bloody Civil War (1967-70) that fundamentally threatened the corporate existence of the country.

The emergency situation of the civil war years coupled with the fact that military dictatorships have become the norm rather than the exception in the social formation provided the state with an ample opportunity not only to further try to emasculate the working class, but also to keep a tight control on democratizing the entire society. The evidence for the former assertion is the various anti-labour decrees that have been added to the nation's statute book. In spite of their existence, however, there is evidence (as the following Table shows) that the workers have frequently resorted to the instrument they have always had - the strike action - to press for their demands. 
Table 1

INDUSTRIAL RELATIONS, W84992

\begin{tabular}{l|l|l|l|l|l}
\hline & \multicolumn{5}{|l}{ Description } \\
\hline Year & $\begin{array}{l}\text { Trade } \\
\text { Disputes }\end{array}$ & $\begin{array}{l}\text { Work } \\
\text { Stoppages }\end{array}$ & $\begin{array}{l}\text { Workers } \\
\text { Involved }\end{array}$ & $\begin{array}{l}\text { Man/Days } \\
\text { Lost }\end{array}$ & $\begin{array}{l}\text { C as a\% of } \\
\text { B }\end{array}$ \\
\hline$A$ & $B$ & $C$ & $D$ & E & $F$ \\
\hline 1970 & 165 & 44 & 14,784 & 27,072 & 27 \\
1971 & $2 \%$ & 165 & 77,104 & 208,114 & 58 \\
1972 & $1 \%$ & 64 & 52,748 & 145,125 & 33 \\
1973 & 173 & 60 & 33,963 & 115371 & 35 \\
1974 & 338 & 129 & $62 \wedge 65$ & 144,881 & 38 \\
1975 & 775 & 346 & 107,489 & 435,493 & 45 \\
1976 & 230 & 125 & 52,242 & 148,141 & 54 \\
$1977^{1}$ & 172 & 93 & 59,270 & 136349 & 54 \\
1978 & 142 & 78 & 105,525 & 875,137 & 55 \\
1979 & 155 & 755 & 204,742 & $2,038,855$ & 487 \\
1980 & 355 & 265 & 221,088 & 2350,998 & 75 \\
1981 & 258 & 234 & 323,700 & $2 \wedge 18,223$ & 91 \\
1982 & 341 & 253 & $2,874,721$ & $9,652,400$ & 74 \\
1983 & 184 & 131 & 629,177 & 404,822 & 71 \\
1984 & 100 & 49 & 42,046 & 301,809 & 49 \\
1985 & 77 & 40 & 19,907 & 118,693 & 52 \\
1986 & 87 & 53 & 157,165 & 461,345 & 61 \\
1987 & 65 & 38 & 57,097 & $142^{\wedge} 06$ & 58 \\
1988 & 156 & 124 & 55,620 & 230,613 & 79 \\
1989 & 144 & 80 & 157342 & 579,968 & 56 \\
1990 & 174 & 102 & 254,540 & 1339,105 & 59 \\
1991 & 204 & 117 & 460,471 & 2,257382 & 57 \\
$1992^{2}$ & 221 & 124 & $2383 \mathrm{H}$ & 966,611 & 56 \\
\hline
\end{tabular}

Source: $\quad$ Federal Ministry of Employment, Labour and Productivity. Quoted by The Central Bank of Nigeria, Statistical Bulletin, Vol.1, Nos. 1 \& 2, December, 1990, p. 109. Also CBN, Annual Report and Statement of Accounts, 1991 \& 1992 editions.

Notes: $\quad{ }^{1}$ Figures are from January to June

${ }^{2}$ Provisional.

It is true that the emerging picture from this Table is pointing to the possible development of 'trade union consciousness', i.e. the agitation by 
workers for an improvement in their conditions of service more than an agitation for strictly political purposes, it should not be forgotten that the periods when trade unionism heightened (i.e. periods when the proportion of work stoppages over declared trade disputes were more than $50 \%$ ), numbered 17 out of the 23 -year time frame (see column 'E' in the Table). This development should in itself be considered a welcome development as over the years the labour laws in this country have generally been aimed at muzzling working class militancy, solidarity, and organization resilience.

As these periods also coincided with both the periods of acute economic travails (viz., 1971, '77, '78, '79, '80, '81, '82, '83, 1985-1992) and of the questioning of the leadership styles (viz., 1979, 1981-1983 and from 1987 to 1992) in the country, both the workers and other progressive groups allied with them - such as the Academic Staff Union of the Universities (ASUU), students' body and the (radical wing of the) press - raised critical political issues. Because of the influence of the latter periods or experiences, the workers got itself mobilized, politicized, and radicalized. It was indeed the attempts to nip this salutary process in the bud that respectively in 1981 and in 1987, the state wanted to set up another (rival) central labour body to the Nigerian Labour Congress (NLC) (which attempt failed) and did intervene in the labour leadership contest (which attempt largely succeeded). (See also the brief discussion below on corporatization by the Nigerian state.)

Military intervention in the country's politics has nonetheless impacted on the way labour's contribution to the democratization process has evolved. In the first place, unity which hitherto was elusive in the labour movement more or less was enforced by the military from 1976. This is referring to the steps taken by the Obasanjo regime to dissolve all the existing central labour organizations, the re-organization of industrial bodies into forty-two trade unions, the requirement for the first time that these unions would have to operate an automatic check-off system to ensure solvency for the central labour body, and the establishment or the emergence of the Nigerian Labour Congress (NLC) as the umbrella organization to the re-organized unions. If unity was meant to create a dynamic leadership for the labour movement, this was largely attained with NLC's first leadership whose style of trade unionism was to seriously shake the corrupt, inept and irresponsible leadership of the Second Republic (1979-1983). ${ }^{49}$ So, corporatization ${ }^{50}$ was never allowed to be on the agenda during Sunmonu's and his successor's (Alhaji Aliyu Chiroma's) tenures.

However, corporatist schemes of the state were never really far off: (i) during Shagari's tenure and particularly at the height of the 1981 General Strike, the state, as already staled unsuccessfully wanted to introduce another central labour body, to correct its alleged violation of the ILO Convention 87 on the Freedom of Association. Apparently, this was meant to foster 'democratization and freedom of choice' in the labour movement, but the basic issue was the state's wish to create a teleguided and pliant labour body, and (ii) after the 1983 military putschism, the state got the opportunity for infiltration and the introduction of its corporatist designs in the wake of the leadership struggle in the NLC in 1987. Currently, the NLC leadership is the weakest labour could or has ever had under a central organ to fight the course of the working class and to champion democratic issues generally. 
(The despicable nature of this compromised leadership was further betrayed in the wake of the political impasse engineered by the military dictatorship, following the annulment of the election results in June 1993.) (See below.)

In the second place, even when the state was allegedly keen on promoting unity in the labour movement, it was quite clear what model of trade unionism it wanted to promote. We have already mentioned the British model of trade unionism that places emphasis on the need to separate political and economic struggles. The workers are thus expected to occupy themselves with economic struggles; their political roles should not go beyond discharging their civic duties to the nation and these could or should be done on an individual rather than on a collective or concerted (class) basis.

Consequently, when the military in 1979 was planning to hand over to the civilians and bearing in mind its predictions for the British trade union model, the class interests being championed by the Nigerian state, and the alleged background of Nigeria's rancorous electoral past, the electoral law was made very stringent. In addition,

The (1979) Constitution effectively shuts out the working class from participation as a class in the political process. The financial requirements for the registration of a political party can be met only by a collection of businesses (sic) and other segments of the ruling class. Section 201 of the Constitution makes it illegal for labour unions to openly and actively support a political party of their choice. (Emphasis in the original.)

Thus, it was only the parties floated by the late Malam Aminu Kano, the late Alhaji Waziri Ibrahim, the late Chief Obafemi Awolowo, Dr Nnamdi Azikiwe, and Alhaji Shehu Shagari that got the Federal Electoral Commission's (FEDECO's) recognition and approval for registration. (Left-wing political associations such as Comrade Ola Oni's Socialist Party of Workers, Youths and Farmers (SPWYF) could not even be given the nod by FEDECO.) To this extent, it could be argued that the politics of the Second Republic was re-incarnation with a few embellishments of the politics of the First Republic. The contradiction of the electoral law, in short, ensured that the dominant theme in the electioneering process was not issues but personalities. To this extent, too, the Second Republic, like the First, failed to foster democratic politics as it alienated the groups in society that mattered most (because of their central roles in production and during decolonization), but who were merely (just as they continue to be) used as electoral fodders.

It did not come as a surprise then that the Second Republic was sacked like the preceding one by the military. The Babangida Administration embarked on another handover to the civilians. Again, the legal instruments under which the transition was undertaken, viz, aspects of the 1992 Constitution (Sections 219, 220, and 227), were truly stacked against the working class. As a class, in other words, the workers were not engaged in politics and, as said above, the contemporary leadership has not been helpful 
in raising the necessary democratic issues. Such issues include the propriety in terms of democratic struggles of the imposed two-party system - the National Republican Convention (NRC) and the Social Democratic Party (SDP) - during the abortive transition programme; the propriety, too, of the continued military incursion into the nation's politics; the democratic imperatives of discussing the nature and state of our economy (Who should own what? Why privatization? What do we owe? By how much and why or what for?); of challenging specific items of expenditure in the nation's resources (for instance; why should soldiers who are not involved in production and not as patriotic as the workers be given motor cars and not the most vulnerable groups in the society?); the insistence on the need for an open and responsible government; for the unfettered and full exercise of the fundamental rights of the citizens to associate and form their political organs, etc., etc. These issues are crucial for the democratic deepening and advancement in the country; and labour has a contribution to make. To succeed in this onerous responsibility, labour needs to be more united; it must first and foremost transcend bureaucratic and synthetic unity as currently constituted, so as to embrace and/or cultivate organic and ideological unity, and it must combine both economic and political struggles as a section of it aspired to do during the anticolonial struggles. Indeed, democracy can be further aided if and only if labour transcends trade union consciousness.

One is inclined to argue that the contemporary labour leadership is not, even at the superficial level, schooled in cultivating this trade union consciousness (see footnote 51 once again). But the political naivety as well as blind allegiance and devotion to a corrupt, dictatorial and undisciplined military leader by the labour leader should be put in its proper perspective. The President of the NLC - Mr Pascal Bafyau (1988-?) was (and maybe still is) a close friend and confidant of ex-President Babangida. When his bid to submit his nomination papers to the SDP National Secretariat for participation in the party's presidential primaries were refused on account of lateness and on the principle of being fair to all and sundry by the National Caretaker Committee, he first went to the National Electoral Commission (NEC) and was told that the decision to accept or refuse to accept the forms was with the party and nobody else.

From there he went to Babangida who directed NEC to ask the party to accept all late forms, ostensibly because, "Mr President wanted to give everybody who was determined and prepared to play a leadership role a chance to do so." ${ }^{55}$ The real motive was, of course, to enable Mr Bafyau to submit his form. His (Mr Bafyau's) desperate need to get into the race was rather disingenuously explained to me at a separate meeting. ${ }^{56}$

All attempts to get Bafyau into the presidential contest failed as his form as well as those belonging to the other late-comers were returned by NEC to the SDP National Caretaker Committee because of the 'reasons given"57 - meaning concretely the principled stand of being fair and just to all the members of the party.

After the SDP Convention in Jos at the end of March 1993, Bafyau began to scheme to become Bashorun Abiola's running mate. This slot was eventually given to Ambassador Babagana Kingibe - the erstwhile rival of 
Abiola for the party's presidential ticket. Bafyau was to pay back Abiola in his own coin (for failing to choose him - a matter which should not be seen as an offence by Abiola, given that the SDP presidential candidate was reserved the right or the final decision to select his running mate) when the dictator annulled the election.

The background to all this was the resolution of the Central Working Committee (CWC) of the NLC to call out the workers to protest the annulment of the election results. When this became public knowledge, ${ }^{58}$ Bafyau as well as the other renegade labour aristocrats went to the State House in Abuja to pledge support and to express solidarity with the dictator, as well as to deny any such course of action. Consequently and for a historic moment, labour missed an opportunity to carry aloft once again the tradition of being part (a significant part for that matter) of the democratization process in Nigeria. This capitulationist display by labour should not be glibly attributed to the success of the corporatist strategies of the state. Rather, the outline of the labour leader's subjective relationship with ex-president Babangida offered in the preceding paragraphs should be more closely noted. ${ }^{59}$

\section{CONCLUDING REMARKS}

The paper has tried to trace the involvement of the working class (of the modern sector of Nigeria's political economy) in the democratization process. It has been shown that the workers have identified, to varying degrees of success as well as failure, with the process. It is assumed that the working class has a greater potential to enhance this process, to its own benefit as well as other groups in civil society. It is pertinent, therefore, that on the basis of the role (both historical and ideological) which the working class has been assigned and which has had to be carried out no matter the terrain, the difficulties involved and the sacrifices required in some climes, the Nigerian labour movement would need to be radicalized to shed, most importantly, its trade union consciousness, in order that through its self-mobilization it can transit to higher forms of politicization and democratization. The revolutionary intellectuals, the student body, and all revolutionaries from classes allied to the workers can help in this regard, too, through placing their organs at the disposal of the workers. Nigeria is still far from being called a democratic polity. This is more so with the frequent interventions of the military in governance and the consequent regimentation of civil society. Similarly, the fitful pre-occupations with 'democratization' since the country assumed a sovereign status from the British imperial system has not offered any promise or hope, especially in a state of working class emasculation and exploitation. 


\section{FOOTNOTES}

1. T. Bottomore, (ed), A Dictionary of Marxist Thought (Oxford: Basil Blackwell Ltd, 1988 edition), p. 267.

2. Ibid.

3. Y.R. Barongo, "The Impact of Military Rule on Working Class Consciousness in Nigeria", in Studies in Politics and Society, Issue No. 3, (April 1985), p. 5.

4. Bottomore, op. cit. See also F. Erigels, "The Origin of the Family, Private, Property and the State" in K. Marx and F. Engels, Selected Works, Volume Three, (Moscow: Progress Publishers, 1983), pp. 191-234.

5. Bottomore, ibid.

6. Unlike the early process of proletarianization in Africa where the urban industrial working class still maintained his title to land and other kinship ties, the accompanying philosophies of individualism and liberalism in Europe completely altered the bourgeois society, to bequeath to the worker the profile of his existence described in the text.

7. The formulation in the text is classically put as follows by Marx: "In the social production of their life, men enter into definite relations that are indispensable and independent of their will, relations of production which correspond to a definite stage of development of their material productive forces. The sum-total of these relations of production constitutes the economic structure of society, the real foundation, on which rises a legal and political super-structure and to which correspond definite forms of social consciousness. The mode of production of material life conditions, the social, political and intellectual life process in general." K. Marx, Preface to A Contribution to the Critique of Political Economy, Selected Works, Vol. I, (Moscow: Progress Publishers, 1983,5th Printing), p. 503.

8. F. Engels, "The Condition of the Working Class in England in 1844" quoted in R. Hyman, Marxism and the Sociology of Trade Unionism (London: Pluto Press Ltd, 1975, Reprint), p. 6.

9. See, Hyman, ibid, passim.

10. The factors responsible for this are rather complex and cannot be looked into here. Lenin's What is to be done! and Imperialism: The Highest Stage of Capitalism provide useful insights into the evolution of the phenomenon of "trade union consciousness" in advanced capitalist societies.

11. See, for instance, the critical analysis made of liberal democracy by B. Barber, Strong Democracy: Participatory Politics for a New Age (Berkeley: University of California Press, 1984), passim. It must be 
stressed that, in spite of its efforts, the book is still situated within liberalism and all its attendant weaknesses.

12. For an analysis of the other varieties of democracy, see C.B. Macpherson, The Real World of Democracy (Toronto; The Canadian Broadcasting Corporation, 1965),passim.

13. See, N. Yaqub, "The Future of Democracy in Africa: Beyond the Transition". Being paper presented at the IPS A Study Group on Democratization: Regional Conference on "Problems of Democratization in Africa", held at the Centre for Democratic Studies, Bwari, Abuja, Nigeria, September 20-24,1992, p. 28.

14. Barongo's conceptualization of the Nigerian working class as a producer class which is clearly identifiable by its participation, directly or indirectly, in commodity production suffices for our purpose here too. See Y.R. Barongo, "The Impact of Military Rule on Working Class Consciousness in Nigeria", in Studies in Politics and Society, Issue No. 3 April 1985, p. $8 . \quad$ In addition, see A. Peace, "The Lagos Proletariat: Labour Aristocrats or Populist Militants?" in R. Sandbrook and R. Cohen (ed), The Development of An African Working Class: Studies in Class Formation and Action, (London: Longman Group Ltd, 1975), pp. 281-302.

15. G. Williams, State and Society in Nigeria, (Idanre: Afrografika Publishers, 1980), p. 30. This "Creation thesis" is accepted and used in the sense that the peasantry was superimposed on a "natural", largely subsistence economy.

16. D.C. Obadike, "Exploitation of Labour: Waged and Forced", in T. Falola, (ed), Britain and Nigeria: Exploitation or Development? (London: Zed Books Ltd, 1987), p. 149.

17. Ibid, p. 152.

18. F. lyayi, "The Class Functions of Nigeria's Labour Laws", in Studies in Politics and Society, Issue No. 3, (April 1985), p. 27.

19. Ibid.

20. Ibid, p. 28.

21. B. Onimode, Imperialism and Underdevelopment in Nigeria: The Dialectics of Mass Poverty, (London: Zed Press, 1982), p. 84.

22. Ibid.

23. Ibid, and lyayi, op. cit., pp. 29-30.

24. Among the works in this genre, see, PA. Baran, The Political Economy of Growth, (New York and London: Monthly Review Inc., 1968, Paperback Edition); A.G. Frank, "The Development of Underdevelopment", in C.K. Wilber, (ed), The Political Economy of Development and Underdevelopment ${ }^{\wedge}$ (New York: Random House, Inc., 
64 Annals of the Social Science Council of Nigeria, No.5,1993

1979, Second Edition, pp. 103-13; and W. Rodney, How Europe Underdeveloped Africa, (London: Bogle-L'ouverture Publications, 1983 Reprint).

25. Among others, see A. Cabral, Revolution in Guinea: An African People's Struggle, (London: Stage 1, 1974), particularly pp. 73-90. Cf. thcl elaboration of the thesis of stages in societal development by J. Slovo, The South African Working Class and the National Democratic Revolution, (An Umsebenzi Discussion Pamphlet published by the South African Community Party, n.d., pp. 13-18; and E. Toyo, "Neocolonialism, Primitive Accumulation and Third World Orientations, (A Clarification of Issues)", in Nigerian Journal of Political Science, Vol, 4, Nos. I and II, 1985, particularly pp. 17-21.

26. It is not possible to give detailed analysis of the class nature of Nigeria and the configuration of the class forces opposed to imperialism/colonialism. It is felt that, apart from what brief allusions have been made in this paper to the different classes in Nigeria, a body of literature already exists that has detailed this. For references, see the individual contributions in O. Nnoli, (ed), Path to Nigerian Development, (Dakar: Codesria Book Series, 1981).

27. For the history of the development of trade unionism before this time and after, especially to the period 1966; see, W. Ananaba, The Trade Union Movement in Nigeria, (Benin City: Ethiope Publishing Corporation, 1969), passim.

28. See, the accounts given by S.O. Osoba, "The Development of Trade Unionism in Colonial and Post-Colonial Nigeria", in LA. Akinjogbin and S.O. Osoba, (eds), Topics on Nigerian Economic and Social History, (Ile-Ife: University of Ife Press Ltd, 1980), pp. 192-95.

29. J. Zasha, "The State and Trade Unions", in Nigerian Journal of Political Science, Vol. 4, Nos. I and II, 1985, p. 122.

30. Osoba, op. cit., p. 198.

31. See, the tribute paid to him by G.G. Darah, "Imoudu and the Labour Movement", in Journal of African Marxists, Issue 9, June 1986, pp. 87-97.

32. Onimode, op. cit., p. 88. See, also Table 1 and the accompanying analysis below.

33. Ananaba, op. cit., $p .44$.

34. For details, see ibid, pp. 59-65.

35. Ibid, p. 263.

36. Details of these for the period under consideration are contained in Ananaba, Ibid,passim; and Osoba, op. cit, pp. 198-202.

37. Some of these individually went into the National Council of Nigeria and the Cameroons (NCNC) and also struggled to affiliate< the Trade 
Union Congress (TUC) with the same party. According to Darah, Imoudu later abandoned the NCNC as a bourgeois party and formed the Labour Party in 1964. "[B]y this, he demonstrated that a workers' party must represent the interest of the working people and to oppose bourgeois opportunism." See Darah, op. cit, pp. 9293.

38. The details of the problem of trade union unity are provided, though in a onesided manner, in Ananaba, op. cit., passim. See, also a more balanced account provided by E. Toyo, The Working Class and the Nigerian Crisis, (Ibadan: The Sketch Publishing Co. Ltd., 1967), passim; and R. Cohen, Labour and Politics in Nigeria (London: Heinemann Educational Books Ltd, 1981 Impression), poy «m.

39. Ananaba, ibid, p. 92; and Cohen, ibid, particularly chapters 3,4,5,7 and 8.

40. For details, see Ananaba, ibid, passim; Cohen, ibid, passim; and Toyo, op. cit., passim.

41. Toyo, ibid, pp. 66-67. See, also Cohen, ibid, passim.

42. For details, see Ananaba, op. cit, pp. 228-52; and Cohen, ibid, passim.

43. The lack of a strong, united working class organization affected the opportunity to transform the crisis of integration into a democratic class struggle. See T. Abdulraheem and A. Olukoshi, "The Left in Nigerian Politics and the Struggle for Socialism: 1945-1985", in Review of African Political Economy, No, 37 (December 1986), pp. 64-80.

44. See, the compilation as an appendix in F. lyayi, op. cit, pp. 31-45.

45. For analyses, see, among others, Yaqub, "The Nature and Impact of State Intervention in Industrial Relations Practice in Nigeria", in The Farfaru Journal of Multi-Disciplinary Studies, Vol. 3, No. 1 (December 1992), pp. 77-86; and Barongo, op.cit; and lyayi, op. cit.

46. The data on industrial relations would from this analysis appear to be incomplete, especially with respect to the extent to which man-days might have been lost, too, when students go on demonstrations not usually considered to be related to industrial relations. But in periods like that, the lecturers do not work and productivity naturally stagnates or even declines from previous levels. For an analysis of the role of student unionism in the political development of the country, see, among others, E. Babatope, Student Power vs. Militarism: Gowon's Dyihg Years, (Ibadan: Sketch Commercial Printing, 1976); - ${ }^{1}$ A Decade of Student Power in Nigeria, 1960-1970, Vol. 1, (Ibadan: 1974); and T.U. Nwala, (ed), Crisis in Nigerian Universities: Underlying Factors and Solutions, (Nsukka: A Publication of the Committee for Free Education, 1978).

47. At about this time there were four rival central labour organizations. They include the United Labour Congress, the Nigerian Workers' Council, the Labour Unity Front, and the Nigerian Trades Union Congress. 
48. For the background to this development, see D. Otobo, "The Nigerian General Strike of 1981", in Review of African Political Economy, No. 22, (OctoberDecember, 1981), especially pp. 65-68.

49. See, ibid, pp. 65-81- for the impact of Hassan Sunmonu's leadership during and after the 1981 General Strike.

50. Corporatism is defined as "a pattern of relationships between the state and interest groups that involves such elements as state structuring of representation that produces a system of officially sanctioned, non-competitive interest associations organized into legally prescribed functional groupings; state subsidy of these associations; and direct (and indirect) state control over their leadership, demand-making, and internal governance". See, individual authors in D. Collier, (ed), The New Authoritarianism in Latin America, (Princeton, NJ.: Princeton University Press, 1979), p. '400; and G.A. O'Donnell, "Corporatism and the Question of the State", in J.M. Malloy, (ed), Authoritarianism and Corporatism in Latin America (Pittsburgh: University of Pittsburgh Press, 1977).

51. The President of the Nigerian Labour Congress, Mr Pascal Bafyau, demonstrated his capitulationist and unnecessary accommodationist proclivities in the 1990 ultimatum to the state to mitigate the harsh economic conditions of the workers and in his unfortunate call on the Babangida's regime (a dictatorship) to continue in office beyond 1993 January scheduled hand-over date. (See, also footnotes nos. 54-57 for the opportunism of this labour leader.)

52. See Electoral Decree No. 73 of 1977 as discussed in A. Kurfi, The Nigerian General Elections 1959 and 1979 and the Aftermath, (Lagos: Macmillan Nigeria Publishers Ltd, 1983), pp. 89-94.

53. Socialist Forum: A Marxist Journal for Social Change, July, 1983, p. 25.

54. Mr Bafyau's nomination forms were collected about forty-eight hours before the closure of receipt of duly completed forms. His emissary was unambiguously informed that, given the stringent conditions for successfully filling the forms (i.e. the need to secure twenty signatures from at least two-thirds of the Local Government Areas (LGAS) of his state) chances were that Mr Bafyau would not make it. The emissary was undeterred; he thus went ahead, and purchased the form. The 'duly' completed form was turned in also forty-eight hours after the closure of receipt of forms. He was told, point-blank that the form could not be received because a few other late-comers had earlier and similarly been rejected whereupon he embarked on the influence peddling described in the text. (This author served as the Secretary of the National Caretaker Committee of the SDP hence his insider knowledge of the unprincipled politics of Mr Bafyau.)

55. The author is paraphrasing Professor H. Nwosu's (NEC Chairman's) statement to the Secretary in the former's office. 
56. Apparently Mr Bafyau was egged on to enter the race to stop Mr Abubakar Atiku's bid for nomination from Adamawa State. (Atiku happened to be a protege of General Yar'Adua (rtd) who Babangida hated to see succeed him.) Discussions between author and Mr Bafyau at Abuja Airport on January 20,1993.

57. Professor Nwosu's letter, January 27,1993.

58. As local (Nigerian) media organs became muzzled with regard to providing accurate account of the developments in the wake of the annulment, it was only from the BBC (British Broadcasting Corporation) and other foreignbased news agencies that news-hungry Nigerians obtained information about Nigeria. In the particular case of the decision of the NLC Central Working Committee, BBC News Broadcast of Monday, June 28,1993, carried the news item; but the visit by the labour leaders to the State House wherein the denial of the strike action was formally announced was beamed through the state-controlled television - the Nigerian Television Authority's Newt Broadcast on Tuesday, June $29,1993$.

59. This point is quite important in that, shortly after the exist of Babangida from office the NLC began to find its bearings, especially when in early November 1993 the Labour Movement gave an ultimatum to the Interim National Government (ING) set up from August 27, 1993, to reverse ING's decision to raise pump price of fuel from seventy kobo to five naira per litre (one hundred kobo make one naira). It did call its members out this time around - an action that paralyzed economic activities in Lagos and other major cities as well as it was a critical factor in the re-emergence of the military in political leadership of the country on November 17,1993. 